\title{
THE INCIDENCE OF TINEA VERSICOLOR IN CENTRAL SWEDEN
}

\section{HELLGREN AND J. ViNCENT}

Department of Dermatology, Faculty of Medicine, University of Trondheim, Norway

SUmmaRy. In a survey of 3302 people in an area of central Sweden, tinea versicolor was diagnosed in $0.5 \%$ of males and $0.3 \%$ of females; all those infected were adults. Tinea versicolor is much less common in Sweden than in the tropics.

\section{INTRODUCTION}

Tinea versicolor (TV) is one of the most common mycotic infections and has a world-wide prevalence. The disease is caused by Pityrosporum orbiculare, which is a normal constituent of the cutaneous flora that becomes virulent, probably by a yeast-to-mycelium conversion (Tosti, Villardita and Fazzini, 1972). The factors affecting its pathogenicity are not fully elucidated although a humid and warm climate (Roberts, 1969), hygiene, nutrition, heredity, high plasma cortisol level and pregnancy may be important (Burke, 1961).

Climate seems to be of crucial significance in the incidence of the disease. Marples (1950) reported that the prevalence may reach $50 \%$ in tropical or subtropical areas (Samoa). High prevalences were also reported by McLennan and O'Keeffe (1966) from New Guinea (42\%), Londero (1964) from Rio Grande do Sul in Brazil (36\%), Vanbreuseghem and Bosmans (1968) from Somalia (31.8\%) and Lahiri et al. (1957) from Calcutta $(28 \%)$. In Europe, the highest incidence has been reported from Rome (3.71\%) by Caprilli, Nazzaro Porro and Passi (1971).

Because there was no epidemiological data on the prevalence of TV in Scandinavia the study we now report was initiated.

\section{Methods}

The investigation was undertaken with a total sampling technique; all the persons within a well-defined geographical area were examined. The chosen area, situated in the middle of Sweden, was Skaraborg county, comprising the rural district of Tiveden and Finnerödja, the town of $\mathrm{Hjo}$ and the municipality and parish of Tibro. The study included 3302 persons (1662 males and 1640 females). The diagnosis of TV was based upon a typical clinical picture of reddish, brown or white, round or irregular, confluent macules with powdery scales, made evident by friction and containing spores and hyphae of $P$. orbiculare. Microscopic confirmation was obtained by methylene blue staining of the material stripped from the lesions (Hellgren and Vincent, 1980).

\section{RESULTS AND COMMENT}

A survey of the total population in the area showed that $0.5 \%$ of the males and $0.3 \%$ of the females suffered from TV. The patients were in the age-group 30-70 years for both sexes, with a majority between $45-60$ years.

Our results indicate that TV is an uncommon disease in Sweden in comparison with the very high frequencies encountered in the tropics. Moreover, this survey confirms that the population mainly affected is postpubertal or of mature age and the occurrence of infection would appear to be related to the development of sebaceous glands. 


\section{REFERENCES}

BURKE, R. C. 1961. Tinea versicolor: Susceptibility factors and experimental infection in human beings. Journal of Investigative Dermatology, 36, 389-402.

Caprilli, F., Nazzaro Porro, M. and Passi, S. 1971. Pitiriasi versicolore. Studio clinico. Bollettino dell' Istituto Dermatologia S. Gallicano, Rome, 7 (2), 71-90.

HeLlGREN, L. AND VINCENT, J. 1980. Svampsjukdomar i huden in Dermatologi og Venerologi, edited by J. Søndergaard, V. Kassis and S. Wadskov, Chr. Ejlers' Forlag, Copenhagen, pp. 341-362.

LAHIRI, K. D., SEN, S., KUNDU, R. AND LAHIRI, M. R. 1957. Tinea versicolor. Indian Journal of Dermatology, Calcutta, 3, 57-58.

LONDERO, A. T. 1964. Dermatomycosis in the hinterland of Rio Grande do Sul (Brazil). Dermatologia Tropica, 3, 64-68.

MARPLES, M. J. 1950. The incidence of certain skin diseases in western Samoa: A preliminary survey. Transactions of the Royal Society of Tropical Medicine and Hygiene, 44, 319-332.

MCLenNan, R. AND O'KeEFFE, M. F. 1966. Superficial fungal infections in an area of lowland New Guinea. Clinical and mycological observations. Australian Journal of Dermatology, 8, $157-163$.

ROBERTS, S. O. B. 1969. Pityrosporum orbiculare: Incidence and distribution on clinically normal skin. British Journal of Dermatology, 81, 264-269.

Tosti, A., Villardita, S. and Fazzini, M. L. 1972. The parasitic colonization of the horny layer in tinea versicolor. Journal of Investigative Dermatology, 59, 233-237.

VANBREUSEGHEM, R. AND Bosmans, J. 1968. Nouvelles observations sur les teignes en République de Somalie. Annales de la Societé Belge de Médecine Tropicale, 48, 513-526. 